\title{
The Medieval Globe
}

Volume 2

Number 2 Legal Worlds and Legal Encounters

Article 7

$12-23-2016$

\section{Common Threads: A Reappraisal of Medieval European Sumptuary Law}

Laurel Wilson

Fordham University, Iwilson@fordham.edu

Follow this and additional works at: https://scholarworks.wmich.edu/tmg

Part of the Ancient, Medieval, Renaissance and Baroque Art and Architecture Commons, Classics Commons, Comparative and Foreign Law Commons, Comparative Literature Commons, Comparative Methodologies and Theories Commons, Comparative Philosophy Commons, Medieval History Commons, Medieval Studies Commons, and the Theatre History Commons

\section{Recommended Citation}

Wilson, Laurel (2016) "Common Threads: A Reappraisal of Medieval European Sumptuary Law," The Medieval Globe: Vol. 2 : No. 2 , Article 7.

Available at: https://scholarworks.wmich.edu/tmg/vol2/iss2/7

This Article is brought to you for free and open access by the Medieval Institute Publications at ScholarWorks at WMU. It has been accepted for inclusion in The Medieval Globe by an authorized editor of ScholarWorks at WMU.

For more information, please contact wmuscholarworks@wmich.edu.

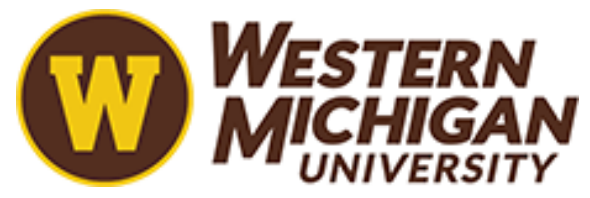




\section{THE \\ MEDIEVAL \\ GLOBE}

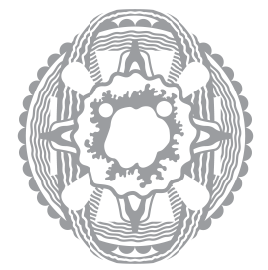

Volume 2.2 | 2016

ARChumanities press 
Copyeditor

Shannon Cunningham

Editorial Assistant

Kelli McQueen

Page design and typesetting

Martine Maguire-Weltecke

\section{(c) 2016, Arc Humanities Press, Kalamazoo and Bradford}

(c) $\odot \$$ This work is licensed under a Creative Commons Attribution-

NonCommercial-NoDerivatives 4.0 International Licence.

The authors assert their moral right to be identified as the authors of their part of this work.

Permission to use brief excerpts from this work in scholarly and educational works is hereby granted provided that the source is acknowledged. Any use of material in this work that is an exception or limitation covered by Article 5 of the European Union's Copyright Directive (2001/29/EC) or would be determined to be "fair use" under Section 107 of the U.S. Copyright Act September 2010 Page 2 or that satisfies the conditions specified in Section 108 of the U.S. Copyright Act (17 USC §108, as revised by P.L. 94-553) does not require the Publisher's permission.

ISSN 2377-3561 (print)

ISSN 2377-3553 (online)

www.arc-humanities.org 


\title{
COMMON THREADS: A REAPPRAISAL OF MEDIEVAL EUROPEAN SUMPTUARY LAW
}

\author{
LAUREL ANN WILSON
}

IN THIRTEENTH-CENTURY SPAIN, no one other than the king was legally permitted to wear a scarlet rain cape; in 1356, the city of Florence proclaimed it illegal for women to have buttons on their clothing without corresponding buttonholes; while in England in 1363, Parliament decreed that only knights and clerics with incomes above a certain amount were permitted to wear linen in the summer. ${ }^{1}$ As puzzling as these restrictions may seem to the modern mind, they were profoundly meaningful to contemporaries, since sumptuary laws such as these were enacted in great numbers throughout Western Europe from the mid-thirteenth century on; there are more than three hundred examples from the Italian city-states alone. ${ }^{2}$

Although scholarly interest in sumptuary law has increased in recent decades, the laws hold far more potential as a historical resource than has yet been realized. To date, moreover, the various bodies of sumptuary law have been studied in geographic and temporal isolation from one another, rather than as a whole, as a large corpus with local variations. It is time to approach sumptuary law on a comparative basis, to allow internal similarities and differences to suggest new meanings and new avenues of research. ${ }^{3}$

\footnotetext{
I Spain: Cortes de Valladolid, 1258: "que ninguno non traya capa aguadera descarlata sinon el Rey" in Cortes de los antiguos reinos, XIV (14), 57. Florence: "Pragmatica of 1356," 2 ("De abottonaturis,"), cited in Rainey, "Sumptuary Legislation in Renaissance Florence," 669. England: Parliament of 1363 (30); cited by Ormrod, "Edward III: October, 1363." It should be noted that, with the possible exception of "England," geographical terms such as "Spain" are anachronistic; here, they allowed to stand as shorthand because they have been the categories that have framed most research on sumptuary law-which is, of course, part of the problem.
}

2 Killerby, Sumptuary Law in Italy, 28-29 (Table 1). Neithard Bulst and his researchers ("Les ordonnances somptuaires," 771) have amassed more than 3,500 sumptuary laws from German-speaking areas.

3 Maria-Giuseppina Muzzarelli has published a plea for less circumscribed study of sumptuary law: "Reconciling the Privilege of a Few"; and Bulst has repeatedly urged the importance of comparative study, for example, in "La legislazione suntuaria." Catherine Kovesi Killerby's Sumptuary Law in Italy compares laws among the various city-states. The only attempt to examine sumptuary law comparatively in all eras and cultures is Hunt, Governance of the Consuming Passions. Hunt is a legal sociologist rather than a historian, but 


\section{What Is Sumptuary Law?}

Sumptuary law is often defined rather vaguely, as laws intended to regulate any kind of consumption of any kind of commodity. Some recent legal scholarship even classifies intellectual property law as sumptuary law, for instance, or describes the 1979 Archaeological Resources Protection Act in the United States as a form of sumptuary law. ${ }^{4}$ Even the word "sumptuary," which strictly speaking should be applied only to sumptuary laws, is now often used to describe goods of widely differing types. ${ }^{5}$ In actuality, sumptuary law was always narrowly focused on personal consumption and almost always aimed at its public display. It might be directed at the construction of lavish houses, as in medieval Japan or precolonial Burma, or, as in many cultures, it might regulate public or semi-public events such as banquets, weddings, and funerals. ${ }^{6}$ Laws governing dress appear to be universal to all sumptuary laws.

Not all sartorial law is sumptuary law, however. One must be careful to distinguish between sumptuary laws and dress codes, as there are substantive differences between the two. Sumptuary law is prohibitive: that is, it claims to prohibit certain groups of people from acquiring and/or displaying certain commodities. Dress codes, however, are prescriptive, that is, they require a certain group, usually a group defined as outsiders, to wear specific clothing (thus, by implication, proscribing other garments): all Jews must wear a particular kind of hat, for example, or all prostitutes must wear yellow; a member of the clergy must wear the dress prescribed for his rank; and so on. ${ }^{7}$ Most important, prohibitive sumptuary law differs sharply from prescriptive dress codes in terms of its enforcement: sumptuary law, which is a society's attempt to discipline itself, is enforced only ambivalently, if at all; while prescriptive dress codes, which generally apply to outsiders and the non-elite, or operate within strictly hierarchical institutions such as the clergy or the military, are relatively easily to enforce and generally are enforced. Thus, although both sartorial codes combine symbolic and instrumental func-

his comparative approach is productive; he is particularly insightful in defining sumptuary law as symbolic rather than instrumental.

4 Beebe, "Intellectual Property Law"; Goddard, "Anticipated Impact."

5 The meaning of "sumptuary goods" ranges from a synonym for luxury goods to "sinful" goods (Moeti and Khalo, Public Finance Fundamentals, 36) to "items of wide distribution not used in daily sustenance" (Miller, Chieftains of the Highland Clans, 10).

6 Shively, "Sumptuary Regulation and Status"; Ware, "Origins of Buddhist Nationalism."

7 In speaking of Islamic laws which make Muslims distinguishable from non-Muslims by their dress, one scholar calls these "laws of differentiation": Schick, "Some Islamic Determinants of Dress," 25. 
tions, sumptuary law is primarily symbolic, while dress codes have a stronger instrumental component. ${ }^{8}$

\section{Sumptuary Law as a Historical Resource}

Sumptuary law provides us with remarkable primary source material. In addition to furnishing details of material goods, it illustrates lawmakers' conceptions of an ideal society. The material details provide insight into patterns of production, consumption, and trade, while the tensions between the actual and the ideal enable us to trace the dynamics of changing class distinctions. The laws make visible changes in the meaning of clothing and other material signifiers, while also providing profound insights into gender and social relations. Relationships between the governing and the governed, strategies of contestation, the connection between law as normative statement and law as practice, along with glimpses of the workings of law courts: all can be investigated via sumptuary law.

Appreciation of sumptuary law as a valid historical source is a relatively recent phenomenon, however. Until the final decades of the twentieth century, many references to sumptuary law treated it as little more than an illustration of the quaint habits of earlier times. ${ }^{9}$ More recently, as interest in the meanings of material culture has grown, sumptuary law has received an increasing amount of attention from medievalists, including literary scholars and art historians as well as economic and social historians. ${ }^{10}$ In addition, feminist historians have been particu-

8 On the distinction between sumptuary laws and dress codes, see Wilson, "Status." Like sumptuary laws, dress codes would repay comparative study, particularly given that certain of them, such as dress codes imposed on religious outsiders, have a wide geographical and chronological range.

9 Susan Vincent, in Dressing the Elite (117), describes the historiography of sumptuary law as "slight, and on occasion slighting." The primary exceptions, other than among historians of dress, are Italian historians who published many medieval sumptuary laws during the nineteenth century, those French historians who included sumptuary laws in their studies of luxury (such as Henri Baudrillart's Histoire du luxe), and a small school of American historians at Johns Hopkins who saw sumptuary laws as akin to Prohibition: Baldwin, Sumptuary Legislation and Personal Regulation; Greenfield, Sumptuary Law in Nürnberg; Vincent, Costume and Conduct.

10 Although this essay is limited to thirteenth- and fourteenth-century sumptuary laws, historians studying later centuries have made considerable use of sumptuary law as a resource. To cite just a few examples: Hayward (Rich Apparel) has used Tudor sumptuary laws to examine changing social structures and the uses of display in reinforcing royal power; Bulst, as mentioned earlier, has examined sumptuary laws as part of the process of state formation (e.g., "Zum Problem städtischer und territorialer"), while Anderssen's recent study of sumptuary laws in seventeenth-century Sweden ("Foreign Seductions") positions 
larly prominent in the more recent studies of sumptuary law, inspired, at least in part, by the almost exclusive focus on women in the laws of the Italian city-states. The earliest work of this kind was done by Diane Owen Hughes, and it continues to be influential. ${ }^{11}$

In addition to exploring gender through the medium of sumptuary laws, Hughes was the first to ask some of the obvious questions: Why were these laws, which their legislators described as ineffective, still passed over and over again? And why in some places and not others? Hughes suggested that urban governments in medieval Italy, and perhaps in southern France as well, enacted sumptuary laws as a way of containing aristocratic display, but that royal governments had different motives. ${ }^{12}$ This suggestion has been followed up to some degree by other scholars, including Neithard Bulst and Sarah-Grace Heller. But there is much more work to be done, since local sumptuary laws from regions that had both municipal and royal or imperial governments (such as southern France, southern Italy, and imperial Germany) are not yet widely available. ${ }^{13}$ Hughes was also the first to voice the crucial idea that it might be the process of legislating rather than the function of the legislation which is significant, that is, that sumptuary law should be considered as symbolic rather than instrumental, an insight which calls for far more attention than it has received to date. ${ }^{14}$

Subsequent to Hughes's work, many Anglophone historians have concentrated on the sumptuary laws of the Italian city-states, notably Catherine Kovesi Killerby. ${ }^{15}$ Carole Collier Frick's work on fifteenth-century Florence has used fashion and dress as historical categories of analysis and thus has touched on sumptuary law as well. ${ }^{16}$ Applying Hughes's feminist approach, Susan Mosher Stuard has

them as a tool for strengthening national identity. Riello has also written extensively on European sumptuary law, primarily from the fifteenth century on (e.g. Riello and Parthasarathi, Spinning World, and Lemire and Riello, "East and West"). See also the essays in Muzzarelli and Campanini, Disciplinare il lusso, which cover European sumptuary laws from the thirteenth century on.

I I Hughes, "Sumptuary Law and Social Relations," "Distinguishing Signs," and "Regulating Women's Fashion."

12 Hughes, "Sumptuary Law and Social Relations," 99.

13 Bulst, "La legislazione suntuaria”; Heller, "Limiting Yardage”; Killerby, Sumptuary Law in Italy, 25.

14 Hughes, "Sumptuary Law and Social Relations," 99. The distinction between symbolic and instrumental legislation is summarized in Gusfield, "On Legislating Morals," 56-59.

I5 Killerby, Sumptuary Law in Italy, "Practical Problems in the Enforcement of Italian Sumptuary Law," and "Heralds of a Well-Instructed Mind."

16 Frick, Dressing Renaissance Florence. 
looked at fashion and the marketplace in fourteenth-century Italy, in addition to studying consumption through the lens of sumptuary law. ${ }^{17}$ Carol Lansing's work uses the funeral laws of medieval Orvieto as a means of exploring both gender and political relationships, suggesting that the men who governed the city were attempting to establish new, regulated patterns of behavior for themselves, but were, in Claude Lévi-Strauss's phrase, "using women to think with." ${ }^{18}$ Another gender-based approach comes from Kim Phillips, who has used English sumptuary laws, directed primarily at men, as a means of studying gender relations and the construction of masculinity. ${ }^{19} \mathrm{~A}$ sign of the new interest being aroused by this topic was the republication of Stella Mary Newton's Fashion in the Age of the Black Prince, in which Newton (an English costume historian) gathered together European sumptuary laws from the 1340s to the 1360s and used them in conjunction with literary, pictorial, and documentary sources to argue for the revolutionary nature of the fashion changes in this era. ${ }^{20}$ (At the time of its initial release, in 1980, it failed to attract attention beyond a very specialized circle of experts.)

Given sumptuary law's symbolic importance, it is not surprising that literary scholars such as Clare Sponsler, Susan Crane, and Andrea Denny-Brown have also been attracted to the subject of English sumptuary law, introducing theoretical techniques and concepts that have broadened the ways in which sumptuary law has been approached. ${ }^{21}$ Sarah-Grace Heller, a literary scholar specializing in medieval France, has also been extremely influential. ${ }^{22}$ French historians interested in social history and material culture have also been drawn to sumptuary law, for example, Françoise Piponnier, Agnès Page, and, for a later period, Daniel Roche. ${ }^{23}$ Many recent scholars of sumptuary law elsewhere in Europe elide the

\section{Stuard, Gilding the Market.}

18 Lansing, Passion and Order.

19 Phillips, "Masculinities and the Medieval English Sumptuary Laws." Compare Lansing, Passion and Order.

20 Newton, Fashion in the Age of the Black Prince.

2 I Sponsler, "Narrating the Social Order"; Crane, Performance of Self; Denny-Brown, Fashioning Change.

22 Heller, "Limiting Yardage," "Anxiety, Hierarchy, and Appearance," and Fashion in Medieval France. Aside from Heller, there has been little Anglophone study of French sumptuary law, with the exception of an American doctoral dissertation on the subject in 1996, of which Bulst justly says that it produced "rather modest results"; Bulst, "La legislazione suntuaria," 121. See also $n$. 24 below.

23 Piponnier, Costume et vie sociale; Page, Vêtir le prince; Roche, La culture des apparences. Curiously, Michel Pastoureau, although he devotes considerable attention to the ordering of 
medieval and the early modern in their investigations, ${ }^{24}$ including Neithard Bulst and Gerhard Jaritz, who have examined sumptuary laws of both French- and German-speaking areas as a means of investigating state formation. ${ }^{25}$

There is, in other words, a valuable body of research on medieval European sumptuary laws. But the work done to date has concentrated on discrete geographical areas and chronological periods, almost without exception. ${ }^{26}$ The virtue of this approach is to enable study of local laws in depth, and much of the published source material which is now available has also resulted from state- or city-state-based studies of sumptuary laws.

Nonetheless, the circumscribed focus of these studies is problematic. Like the parable of the blind men and the elephant (where one man feels the trunk and says the creature is a tree, while another feels the tail and says it is a rope), the limited scope of these individual studies has led to contradictory conclusions. Sumptuary laws are directed primarily at men; sumptuary laws are directed primarily at women. They represent the efforts of the nobility to control the bourgeoisie; they represent the efforts of the bourgeoisie to restrain the nobility; they emanate from the king in an attempt to control the bourgeoisie, the nobility, or both. Sumptuary laws are rarely/never/always enforced. Their primary motive is anti-luxury, economic, mercantilist, paternalistic, moralistic, religious, and so on. And indeed, all of these conclusions are accurate for one or another time or place-but none of them are universally true. The only way to discover the universals is to examine sumptuary law on a macro level, to treat it as an integrated whole with regional and chronological variations.

\section{Comparative Views}

Sumptuary law is an ideal subject for comparative study on a global basis, since it is a widespread phenomenon, both geographically and chronologically: there have been attempts to regulate the display of consumption in many societies, including ancient Greece and Rome, Imperial China, Tokugawa Japan, the Islamic world, Aztec Mexico, and Colonial America. I have limited this article to the earliest post-

medieval dress in terms of color, fabric, mottos, heraldry, and so on, has paid surprisingly little attention to sumptuary law.

24 See the articles in Muzzarelli and Campanini, Disciplinare il lusso, for summaries of scholarship on sumptuary law as of 2003.

25 Examples include Bulst, "Zum Problem städtischer und territorialer"; Jaritz, "Kleidung und Prestige-Konkurrenz."

26 See notes 1 and 3 above. 
classical sumptuary laws of Western Europe, specifically the laws which appeared in the territories of Spain, Italy, France, and England in the thirteenth and fourteenth centuries. ${ }^{27}$ This was the formative period for the templates of European sumptuary law on which most later laws were based; by the fifteenth century, the meaning and uses of these legal templates had changed considerably, and would do so even more in later centuries. I have further limited myself to clothing-related laws, in part because they are the most common, but also because they offer a way of investigating the drastic changes in the meanings of dress and its materials in this period. ${ }^{28}$ I have also chosen to study the form and content of the laws themselves, and not the preambles attached to them, which require a different sort of analysis because they are filled with rhetorical tropes, many of which are common to sumptuary laws in general, and they often reflect contemporary "moral panics" that have little to do with the subject of the laws. In short, the preambles to sumptuary laws deserve a comparative study of their own, which space does not permit here.

Cross-regional comparisons of medieval sumptuary laws raise many questions that have not yet been explored. Why was there more legislation of sumptuary law in one area than in another: hundreds of laws in the Italian city-states versus single-digit numbers in England and in northern France, for example? Why was there no sumptuary law in Flanders until 1497, despite the fact that Flanders was a center of commerce and industry, boasting many powerful and rich members of the urban elite? Judging from the visual evidence, Flanders was also a center of elaborate fashion and rapid fashion change, making the absence of sumptuary law even more intriguing. ${ }^{29}$ Comparative investigation also raises many questions related to gender. The Italian city-states targeted women almost exclusively in their sumptuary laws, and the laws in Germany and southern France were often

27 On the inevitable anachronism of these geo-political categories, see note 1 . In this article, "medieval" sumptuary laws refer specifically to the laws which fall within these chronological limitations, for the reasons noted above. There is one known twelfth-century law restricting the wearing of fur, enacted in Genoa in 1157: Killerby, Sumptuary Law in Italy, 24; Stuard, Gilding the Market, 4. There was also thought to have been a sumptuary law enacted in France by Louis VIII in 1229, but Heller has proven that it did not exist: "Anxiety, Hierarchy, and Appearance," 317, n. 23.

28 See below on the relation of sumptuary laws to the development of the so-called "Western fashion system" during this period.

29 On the chronology of Flemish sumptuary law, see Buylaert, DeClerq, and Dumolyn, "Sumptuary Legislation." For visual evidence of the fashionableness of Flemish dress, see, for example, the Magic Carole in Lancelot du Lac, illustrated in Hainaut, 1344 (Paris, Bibliothèque nationale de France, MS fr. 122, fol. 137v), or almost any illustration in the Roman d'Alexandre illustrated in Flanders ca. 1340 (Oxford: Bodleian Library, Ms. Bodl. 264). 
aimed at women, too-so far as can be known from the sparsely published evidence-while in other places the laws were directed primarily, although not exclusively, at men. Is there a connection between the power of municipal governments and sumptuary laws which focus on women $?^{30}$ More generally, is it possible to relate the ways in which gender is targeted to a specific system of government? ${ }^{31}$ The first step towards answers to these questions is to compare the structure and content of the laws.

\section{Patterns of Difference}

The earliest European sumptuary laws can be roughly divided into two groups according to their structure, content, and chronology (see Table 2). One group, the French and English laws, show striking similarities in chronology, with gaps in both cases of a century or more between the first sumptuary laws and subsequent ones. Two extensive sumptuary laws were enacted in France, in 1279 and 1294 respectively; the next substantive law was passed in 1485. In England there was a limited sumptuary law in 1337 and an extensively detailed one in 1363; the law of 1363 was repealed in the next Parliament, and the next sumptuary law was not enacted until 1463, although unsuccessful attempts were made to pass similar laws in the intervening years. The structural similarities are equally striking. In both the French and English laws, the actual objects being regulated, though they may be specified, are secondary to a detailed focus on permissions and prohibitions expressed in terms of status categories, which are defined in both cases by a combination of social status and income. ${ }^{32}$ The English law mentions approximately thirty socio-economic categories, from knights with a certain income on down to oxherds; it ignores the upper nobility entirely. At the top are two categories of knight, divided by wealth, followed by two categories of esquire,

30 See Lansing, Passion and Order. Lansing suggests that the communes were in the process of creating their own ideal democratic societies, and were thus very concerned with sources of disorder, including their own violent emotions, which they then projected onto women.

31 This is a suggestion originally made by Hughes ("Sumptuary Law and Social Relations," 73-74), but no conclusive answer has been reached.

32 The similarity between these two groups of laws is perhaps not accidental, as suggested by an undated memorandum addressed to Edward I at the end of the thirteenth century. The anonymous writer suggests that a law similar to the recent French sumptuary laws would be an effective way of raising money for the war, and supplies possible details based on the French laws. There is no evidence that this memorandum ever reached Edward, and it is clearly meant as a project for taxation, but it does suggest that the French laws were known in England. See Langlois, "Project for Taxation." 
Table 2. A Comparative Survey of Western European Sumptuary Laws, Thirteenth and Fourteenth Centuries*

\begin{tabular}{|c|c|c|c|c|}
\hline & SPAIN & ITALY & FRANCE & ENGLAND \\
\hline $\begin{array}{l}\text { Gender: } \\
\text { directed at }\end{array}$ & $\begin{array}{l}\text { primarily } \\
\text { men }\end{array}$ & women & $\begin{array}{l}\text { primarily } \\
\text { men }\end{array}$ & $\begin{array}{l}\text { primarily } \\
\text { men }\end{array}$ \\
\hline $\begin{array}{l}\text { Material } \\
\text { details }\end{array}$ & $\begin{array}{l}\text { ornamentation } \\
\text { and color }\end{array}$ & $\begin{array}{c}\text { ornamentation } \\
\text { and cut }\end{array}$ & $\begin{array}{l}\text { cloth and } \\
\text { cost }\end{array}$ & $\begin{array}{l}\text { cloth and } \\
\text { cost, some } \\
\text { ornament }\end{array}$ \\
\hline $\begin{array}{l}\text { Number } \\
\text { of status } \\
\text { categories }\end{array}$ & variable & $\mathrm{n} / \mathrm{a}$ & $30+$ & \pm 25 \\
\hline $\begin{array}{l}\text { Income level } \\
\text { included for } \\
\text { categorization }\end{array}$ & no & no & yes & yes \\
\hline $\begin{array}{l}\text { Classes } \\
\text { affected }\end{array}$ & $\begin{array}{c}\text { variable; } \\
\text { primarily } \\
\text { nobility and } \\
\text { knights, some } \\
\text { bourgeoisie }\end{array}$ & $\begin{array}{l}\text { knights, } \\
\text { doctors, } \\
\text { lawyers }\end{array}$ & $\begin{array}{c}\text { aristocrats, } \\
\text { knights, upper } \\
\text { bourgeoisie; no } \\
\text { lower classes }\end{array}$ & $\begin{array}{c}\text { knights } \\
\text { down through } \\
\text { peasants; } \\
\text { no nobility }\end{array}$ \\
\hline Enacted by & king & towns & king & Parliament \\
\hline $\begin{array}{l}\text { Enforced } \\
\text { by/via }\end{array}$ & $\begin{array}{c}\text { unknown; } \\
\text { fines specified }\end{array}$ & $\begin{array}{c}\text { fines and an } \\
\text { enforcement } \\
\text { apparatus }\end{array}$ & $\begin{array}{c}\text { unknown; } \\
\text { fines specified }\end{array}$ & no \\
\hline $\begin{array}{l}\text { Knightly } \\
\text { classes }\end{array}$ & $\begin{array}{l}\text { mentioned } \\
\text { most often }\end{array}$ & $\begin{array}{l}\text { specifically } \\
\text { excluded }\end{array}$ & $\begin{array}{l}\text { described } \\
\text { in detail }\end{array}$ & $\begin{array}{l}\text { described } \\
\text { in detail }\end{array}$ \\
\hline
\end{tabular}

* This table is illustrative, not exhaustive, and it excludes many regions of Europe that regularly enacted sumptuary laws, such as German-speaking lands. Information on sumptuary laws repeatedly enacted in the territories of Spain and Italy has been derived and synthesized from Gonzalez Arce, Apariencia; Sempere y Guariños, Historia del Luxo; Rainey, "Sumptuary Legislation"; Killerby, Sumptuary Law in Italy. In France and England, where the laws were not repeatedly enacted during this period, data is limited to the French law of 1294 (Heller, "Anxiety, Hierarchy, and Appearance") and the English law of 1363 (see the introduction to Edward III, 1351-1377, ed. Ormrod). 
two categories of clergy, and two categories of urban dwellers, all divided similarly. ${ }^{33}$ There are also three lower ranks, of which the lowest specifically includes carters, plowmen, wagoners, oxherds, cowherds, shepherds, pigherds, threshers, and so on. Careful and specific equivalencies have been set up between groups. Urban bourgeoisie on the one hand, and the "esquires and gentils gens" on the other, are allowed the same clothing and ornaments if the income of the bourgeois is five times that of the esquire; meanwhile, upper clergy are equivalent to the lower rank of knights and lower clergy to the lower ranks of both esquires and bourgeoisie. Even the income qualifications show subtle class distinctions: knights' income is measured in marks, which was a money of account rather than actual specie, and their income was to be from "lands or rents"; the income of the esquires is also specified as "land and rents" but measured in pounds; while the clergy's income is simply stated as marks per year. The incomes of the bourgeoisie are measured in pounds, but not calculated annually. Instead, the law specifies that they must "clearly" (clerement) possess goods and chattels of the appropriate value. There is a certain amount of material detail, though far less than that found in the Spanish and especially Italian laws. Particularly in the lower categories of society, the descriptions of forbidden items are rather general, although the maximum price of the cloth which may be worn by each group across the spectrum is finely graded, with permitted prices differing between categories by as little as half a mark per ell. ${ }^{34}$

It is somewhat more difficult to summarize the patterns discernible in the French laws. ${ }^{35}$ Like the English regulations, they stipulate the maximum cost of permissible cloth, but the French regulations also prescribe the maximum number of robes, or sets of garments, permitted per social category per year, and the groupings are not always parallel. For example, a baron with an annual revenue of 6,000 livres tournois may have four sets of robes, spending a maximum of 25 sols tournois per year, while a prelate (of unspecified income) may use the same cloth but is only permitted two sets of robes per year. As may be seen from this example, the construction of socio-economic categories is remarkably complex, as is the breakdown of permissible expense. By my count there are eight separate prices per aune (a unit of measure) listed, with a wealthy bourgeois being permit-

33 This law marks the first official appearance of "esquire" as a recognized status: Coss, "Knights, Esquires, and the Origin of Social Gradation in England," 155-56.

34 An ell is a unit of measurement roughly equivalent to a yard, as is the aune used in French laws.

35 I have used the law of 1294 for purposes of this discussion: it is quite similar to the law of 1279 , but lists a larger number of ranks. See Heller, "Anxiety, Hierarchy, and Appearance," for tabular breakdowns of both laws. 
ted material costing $12 \frac{1}{2}$ sols tournois per aune, exactly half of the 25 sols per aune permitted to the highest ranks. However, these early French laws are unique in that they contain no material details of clothing, cloth or ornamentation at all; it is the number of garments and the cost of materials that is at issue. Indeed, the law is aimed primarily at the nobility, from dukes down to vavassors, or sub-feudatories, who are ranked even below the bourgeoisie. Only two ranks are accorded to the latter: those with income of over 2,000 livres tournois, and those with income below that figure, with a separate category in each rank for their wives. ${ }^{36}$ By contrast, the upper ranks are broken down with particular precision. One-fourth of the categories, eight ranks, are devoted to the clergy alone; an even greater proportion of the categories are devoted to the "knightly" ranks: there are ten different gradations covering knights, bannerets, squires, and their companions (eleven including the vavassors).

Although women were clearly not an afterthought in this law, they make up a relatively small proportion of the total categories: six ranks, less than one-fifth of the total, are devoted to women. There are three categories of wives (in the higher ranks and in the two categories of bourgeois) and, unusually, three exclusively female categories, confined to the higher ranks alone (dame, damoiselle, and chatelaine), which are not dependent on marital status. And while the wealthy bourgeois mentioned above was limited to fabric costing $121 / 2$ sols per aune, his wife was permitted to spend up to 16 sols per aune; no such gender gap exists for the higher ranks.

The early sumptuary laws enacted in England and France, then, itemize rank and socio-economic categories with great specificity, while treating the material objects in question with far less detail. The structure of the early laws in the other contemporary group, exemplified by the Spanish and Italian laws, is the inverse. Here, the objects rather than the status categories are itemized in detail, concentrating on specific types of clothing, ornamentation, or color ${ }^{37}$ And unlike the sporadically enacted laws of England and France, these laws began in the midthirteenth century and thereafter were passed repeatedly. Given the resultant number of laws, their content cannot be compared as systemically as that of the smaller sample of French and English legislation. Still, comparisons are possible if we focus on two locales which typify the whole: the laws of Castile and the laws of Florence as the primary Spanish and Italian examples respectively.

36 The livre tournois was not actual specie but a money of account, comprising 20 sous/ sols/solidi tournois.

37 See note 1 above, on the clause entitled de abottonaturis in a mid-fourteenth century Florentine law. 
Spanish sumptuary law is obsessively focused on banning certain kinds of ornamentation. For example, in the earliest legislation, which emanated from Jaime I of Aragon in 1234, there are prohibitions against clothing which has been cut, or which trembles (vestas incisas [. . . vel trepatas) - that is, clothing with slashes or possibly dags-striped clothing, orphreys, fringe, and so on. ${ }^{38}$ In addition, the wearing of fur which has been cut or worked over (aliam pellum fractam, vel recoctam) was prohibited, and whole ermine or otter furs were permitted only as trimming on hoods and sleeves. ${ }^{39}$ Other things which clothing may not display include gold and silver, various kinds of gold and silver thread and embroideries, all very specifically described, and several other kinds of fur. Another area of detail, which is almost unique to the Spanish laws, is a focus on color, as exemplified by this passage from the Cortes de Valladolid of Castile in the mid-thirteenth century: "no squire may wear white furs or scarlet stockings; or wear scarlet, green, dark brown, pale green, brown, orange, pink, blood-red, or any dark-colored clothing." ${ }^{40}$ Similarly, in a slightly later compilation from Castile, the Siete Partidas, there is a list of colors (red, dark yellow, green, and purple) which knights should wear when young because they confer lightheartedness (diesen alegría), and a proscription against darker colors because they bring sadness. ${ }^{41}$

The social categories of Spanish sumptuary law are also described with some specificity. Although there are some references to different ranks of city dwellers, it is on the nobility that the thirteenth-century laws find their focus. The highest nobility-the king's brothers, dukes, marquesses, princes, counts, and viscounts-are the ricos homes; the king is actually included in many of these laws, albeit in ways which set him apart from the ricos homes, including his brothers,

38 Dags are ornamental shapes cut into the borders of garments, made possible by the heavily fulled broadcloth developed in the later Middle Ages, which did not fray when cut or notched. Dagging was increasingly popular from the thirteenth century on, and considered very fashionable; at the same time, it was often associated with marginal groups and outsiders. See Denny-Brown, "Rips and Slits," and Friedman, "Iconography of Dagged Clothing." Orphreys are bands of rich embroidery, usually done with gold thread, and most often used on ecclesiastical clothing.

39 Transcribed in Juan Sempere y Guariños, Historia del Luxo, 72-73. All translations are mine unless otherwise indicated.

40 Real Academia, Cortes de los antiguos reinos, XIV, (22), 59: "ningun escudero non traya penna blanca ni calcas descarlata, nin uista escarlata nin uista verde nin bruneta nin pres nin morete nin narange nin rrosada nin sanguina ninningun panno tinto."

4 I Castile, Les siete partidas, 211-12. There are similar laws in some of the Italian citystates, requiring the wearing of bright colors to dispel sadness or increase prestige. Muzzarelli gives examples from Reggio Emilia and Ferrara (“Una società nello specchio," 26). 
to whom certain laws and prohibitions were specifically directed..$^{42}$ Below these are the lower nobility, including noble knights, non-noble knights, and even bourgeois knights, with various urban categories below them. As in France, and to a lesser degree in England, the categories of knights increased over the thirteenth and fourteenth centuries.

Aside from their chronology, what the representative Italian laws have in common with the Spanish is a preoccupation with the details of dress and ornamentation, carried to an even greater extreme. For example, the Florentine statutes of 1322-25 prohibited (under penalty of a high fine) "clothes with cut, worked, or superimposed images or likenesses of trees or flowers, animals or birds, or any other figures," while the Florentine Pragmatica of 1356, which contained the regulation on buttons quoted at the beginning of this essay, also contained detailed specifications governing the conditions under which it was permissible to wear one "single-layered fringe [fregiaturam fregii simplice] with gold or silver but without enamel or anything else ornamenting it." ${ }^{43}$ Moreover, this ornament could not be larger than a certain size and it could only be worn in certain places on certain garments, each one of which is specified. It is also specified that this type of fringe may not be worn on

robes which are dimecçate, that is single or double samite or made of samite and wool cloth or samite and silken cloth or camel's hair [. . . ] nor on any tucked [?rimbocchatura] cloth of camel's hair or sindon [light silk] or ermine or rabbit [...] except that tucked cloth may be worn with impunity over a mantel. ${ }^{44}$

This level of detail is devoted only to clothing and ornamentation, however; when it comes to social classifications, the Italian laws are notably concise. In contrast to all the other laws we have examined, knights, doctors, and lawyers are the only categories mentioned, and then only to exempt them from the laws to which everyone else is subject. More correctly, I should say the wives of knights, doctors, and lawyers are exempt, since the Italian sumptuary laws were directed primarily at women, in contrast to most other European sumptuary laws. Men are mentioned occasionally, and there were even a few prosecutions of Florentine men in the

42 Note the distinction between ricos homes, who are the uppermost level of the nobility, up to and including the king's brothers, and hombres ricos, who are simply rich men. Gonzalez Arce, Apariencia y poder, 133.

43 Statutes of 1322-25, from Rainey, "Sumptuary Legislation," 97. The Pragmatica of 1356 is reproduced in full on pages 667-93.

44 Rainey, “Sumptuary Legislation,” 668-69. 
1340s for wearing pleated garments, which seem to have been a cause of particular anxiety for both women and men. But essentially, the laws concerned the clothing and ornaments of women. ${ }^{45}$

\section{Commonalities: Enforcement and Effectiveness, Status and Social Change}

Having examined some of the differences in content and structure among the earliest medieval sumptuary laws, it is time to explore some of the common features which emerge when they are considered as a group. Two areas are of particular interest: questions of effectiveness and enforcement, approached comparatively, offer insight into the nature and function of the laws themselves; while a comprehensive view of the treatment of social rank opens up a number of perspectives into changes in social dynamics.

Almost without exception, European sumptuary laws were accompanied by weak, inconsistent, or nonexistent enforcement, followed by complaints that the laws had been impossible to enforce, coupled with repeated and often increasing attempts to pass new laws, which would prove unenforceable in their turn. Although such complaints are clearly rhetorical tropes, and appear even in the preamble to the English law of 1463 (when there had been no prior laws in effect for a century), they must still be subject to careful scrutiny. ${ }^{46}$ They cannot simply be regarded as evidence that sumptuary laws were intended to be instrumental, did not affect behavior, and therefore were failures. When sumptuary laws are approached on their own terms, it becomes clear that their paradoxes and ambivalences are a function of their symbolic importance and idealism. Rather than being indications of failure, these inconsistencies are valuable clues to the meanings ascribed to these laws and evidence of the resistance and contestation which invariably arose in response to their enactment and publication.

One indication of the laws' symbolic nature is precisely the fact that enforcement efforts ranged from nonexistent to ambivalent; nowhere do we see a pattern

45 Gender is an obvious target for the kind of comparative approach which I am suggesting, but at this point it seems to me that there is not yet enough information available to undertake such a study. Until we have gathered a substantial number of the municipal laws from southern Italy and southern France, which may well have been focused on women, it is difficult to make any systematic comparisons. And, as with the other areas of comparison which I have suggested, a representative sample of the sumptuary laws from German lands, both municipal and imperial, is sorely needed.

46 Doda, “'Saide Monstrous Hose,'” 178. 
of consistently enforced obedience. ${ }^{47}$ Among the laws we have just examined, the English law contains no specified punishment or enforcement mechanism; while the French and Spanish laws contain schedules of fines, in some cases quite hefty, but, again, no enforcement mechanism. During this early period there is little in the known records of England, France, or the Christian areas of Spain to suggest that people were changing their behavior in order to avoid contravening the sumptuary laws-indeed, it is possible that we are more aware of the existence of these laws than many of the groups who would have been affected by them. ${ }^{48}$

This is not the case in the Italian city-states, where there are records of prosecutions, as well as documented forms of resistance and efforts to circumvent the laws. ${ }^{49}$ Nonetheless, even here the laws were ambivalently enforced and the prosecutions relatively few. Sometimes, the laws gave rise to a licensing system: in Florence, for example, as early as 1290 , we find a reference to registering garments and recording a payment, a kind of commodity tax or gabella, for the privilege of wearing forbidden objects. But this system, too, was practiced inconsistently: licensing fees were more prevalent when the commune was in need of money, while at other times the fines were clearly intended as actual punishments. Nonetheless, the practice of paid exemptions continued to the point where, in 1373, what had been ornamenta vetita, "forbidden ornaments," were now gabellata, taxable. ${ }^{50}$ And although stricter laws, permitting no exemptions, did make a brief reappearance later in the century, the licensing system ultimately prevailed. ${ }^{51}$

47 This is not a universally held view; the evidence of enforcement is sufficiently patchy that it has been variously interpreted as evidence both for and against regular enforcement. Killerby, for example, who refers to Italian sumptuary law as a "manifest failure," nonetheless believes that the Italian laws were generally enforced, and that they were passed repeatedly precisely because they were being obeyed: as individuals continually found ways to get around the laws, the laws required continual rewriting: Sumptuary Law in Italy, chapter 7, "Problems of Enforcement and the Failure of Sumptuary Law."

48 Attempts have been made to compare wills and inventories with the sumptuary laws in force in a given area, e.g., Burkholder, "Threads Bared," but I find that the documents do not consistently give enough information to firmly fix the person's status according to the laws.

49 See Sacchetti, Novelle, 137, in which he describes some of the ways that women evaded officials attempting to enforce the laws. According to Rainey, Sacchetti based his novella on the actual experiences of one of the uffiziali delle donne, the "women's officials" charged with enforcing the law. See Rainey, "Sumptuary Legislation," 234.

50 Rainey, "Sumptuary Legislation," 206.

5 I The licensing/money-raising aspect of the laws appears elsewhere as well: compare, for example, the statute in Munich which required a man who wished to wear colored shoes to supply an archer to the city. Bulst, "Les ordonnances somptuaires," 779. 
If sumptuary laws were indeed largely ineffective in the instrumental sense, as measured by enforcement and compliance, the effectiveness of symbolic legislation is not related to enforcement or to the impact of the legislation on behavior. Rather, its purpose was to demonstrate or affirm certain values, to elevate the values of a particular group, to create or underscore group or national identities. ${ }^{52}$ For example, in ancient Rome, rulers enacted sumptuary laws to demonstrate that they were still in touch with the traditional virtues, the mos maiorum of their ancestors. ${ }^{53}$ Given that another common trope in the preambles to medieval sumptuary laws is a lament that the traditional virtues of an earlier golden age have vanished, it is likely that this was one of the major motivating forces behind the repeated enactments of sumptuary law in the thirteenth and fourteenth centuries, for kings and municipal governments alike.

But if the primary meaning of sumptuary law-to lawmakers and citizens alike-was as a symbolic statement about virtue and social order, it is clear that the common conception of sumptuary law as a means of social control, or restriction of goods to one or another class, must be completely re-examined.

The other common characteristic which is immediately noticeable in looking at Western European sumptuary laws as a group is that all are focused in one way or another on knights and the bourgeoisie. The nobility may or may not be involved; the lower classes may or may not be involved; but the laws always include knights and urban merchants and professionals. The focus may have been on strengthening the knightly ranks, as in the Spanish laws; knights may have been exempted from the laws, as in Italy; knights may have been made subject to the laws through a carefully graded and increasing series of ranks, as in England and France. Urban populations, too, are targeted. They may be divided into groups by income, as in England and France; referenced as comprising the bourgeoisie (France); specified as merchants and/or the wealthy (England and Spain); or inclusive of doctors and lawyers (Italy). And one or both groups may also be driving the actual legislative process (England and Italy). But, regardless of the shape which their involvement takes, the knightly ranks and the bourgeoisie were always at the center of thirteenth- and fourteenth-century sumptuary law.

Indeed, because the focus on these two groups remains constant, changes over time are more easily visible. One of the most obvious is the change in the number of ranks, on all levels. For example, in the French sumptuary law of 1279, there

52 Gusfield, "Moral Passage," 228.

53 Zanda, Fighting Hydra-Like Luxury, 159. Compare Diane Owen Hughes's suggestion that urban sumptuary laws might be seen as "a symbol of republican virtue": "Sumptuary Law and Social Relations," 74. 
are fourteen categories listed. The only knightly rank listed is escuier (squire or esquire), and it is divided into two groups by income level. Fifteen years later, when the second law was enacted, the total number of categories had increased from fourteen to thirty-two, of which eleven were gradations of knightly status. In England, the sumptuary law of 1363 contains the first mention of the category of "esquire." ${ }^{54}$ In, Spain from the thirteenth century on, there were a variety of levels within the noble knightly groups, with the knights who carry banners (rico home que haya pendón) being the highest status, and further distinctions among knights who may wear sashes (caballeros de la banda) and non- or less noble knights. ${ }^{55}$ In the fourteenth century, urban knights (caballeria villana: knightly members of the bourgeoisie) became more powerful, though they had existed for some time; and here, too, additional gradients were added as time went on. ${ }^{56}$ Once again, Italy appears to be the exception, since the only social categories mentioned-with the exception of servants and slaves-are those listed as exempt. Despite the lack of the subtle gradations found elsewhere, however, the Italian laws share with all the others a focus on the knightly and professional classes, since these were precisely the groups exempted from the laws. ${ }^{57}$

All of the bodies of sumptuary laws we have considered, whether royally promulgated or stemming from a municipal government, display an intense focus on the interzone shared by the knightly class and the upper bourgeoisie, including professionals such as doctors and lawyers, as well as the lower nobility in many cases. The formation of this status bracket into a relatively self-aware group is often described as the rise of the "urban elite" (though I prefer the wider English term "gentry") and it has been a subject of much scholarly interest in recent decades. ${ }^{58}$ And while sumptuary laws have not been overlooked entirely in the resultant studies, they have not been considered on a comparative basis. Once again, a number of avenues remain to be explored. For example, outside of Eng-

54 Similarly, the 1463 sumptuary law contained the first use of "gentleman" as a specific rank.

55 Gonzalez Arce, Apariencia y poder.

56 Although the articles in Asenjo-Gonzalez, Urban Elites, are primarily devoted to urban elites in the Christian Spanish kingdoms of the fifteenth century, they show, if only by implication, the increase and permeability of social categories in the previous centuries.

57 Catherine Kovesi Killerby has summarized the exempt statuses listed in the group of laws which she studied; out of a total of nearly two hundred mentions, well over half are of knights, doctors, and judges; counting mentions of related statuses such as "magistrate," the proportion is even higher: Sumptuary Law in Italy, 85 (Table 4.2).

58 See Coss, Origins of the English Gentry; and Lachaud, "La 'formation de la gentry,", for the history of the construct of the gentry in the English context. Dumolyn, "Later Medieval and 
land, the rise of the gentry is often thought to have occurred in the fifteenth and sixteenth centuries. While the dynamics may have become more obvious or taken on a different character in later centuries, the attention paid to this very group in the thirteenth- and fourteenth-century sumptuary laws suggests that the chronology deserves another look.

The focus on the gentry also helps to elucidate the frictions and contestations which were taking place within this grouping, as exemplified by the history of the English sumptuary law of 1363. Like all Parliamentary legislation at the time, this law originated with a petition to the king from the Commons, a body which was composed of two knights from each shire, and two citizens or burgesses from each city or borough-in other words, a representative group of gentry. ${ }^{59}$ And yet it was presumably an equally representative group of gentry who were responsible for the immediate repeal of the statute, in the following Parliament, alleging that the statute had caused great financial harm, though there is no evidence that it was either enforced or obeyed. It seems likely that the immediate repeal, as well as the initial passage of the statute, resulted from conflict among the various segments of the gentry which made up the Commons. The friction and contestation among the various components of the gentry are rarely so clearly demonstrated, but a comparative examination of the multiple iterations and occasional repeals of sumptuary laws offers another way of making those dynamics more visible. ${ }^{60} \mathrm{~A}$ comparative study of the preambles to thirteenth- and fourteenth-century sumptuary laws might offer insights as well.

Another area of evident interest is the connection between sumptuary law and fashion. The emergence of the so-called "Western fashion system" in the later Middle Ages is now generally accepted by most medievalists and fashion scholars. ${ }^{61}$

Early Modern Urban Elites," is an extended discussion of the various terminologies applied to the powerful as a group (such as elite, aristocracy, patriciate), including a consideration of the general application of "gentry."

59 There is an enormous literature on English Parliamentary legislation. For the origin of legislation in the Commons, see, most recently, Dodd, Justice and Grace. For the composition of the Commons, see Brown, Governance of Late Medieval England, 180.

60 There seem to have been repeals of the Spanish regulations from time to time for similar reasons. Gonzalez Arce gives an example from Madrid in 1339: Apariencia y poder, 98.

6I Representative fashion scholars include Laver, Concise History of Costume; Wilson, Adorned in Dreams; Lipovetsky, L'Empire de l'éphémère; Breward, Culture of Fashion; Hollander, Sex and Suits. Representative medievalists include Heller, Fashion in Medieval France; Blanc, "From Battlefield to Court"; Newton, Fashion in the Age of the Black Prince; Stuard, Gilding the Market; Crane, Performance of Self. Early modernists have located the advent of a fashion system somewhat later, generally in the eighteenth century. 
This system is generally thought to have been fully developed by the mid-fourteenth century, although medievalists have variously located its beginnings in the thirteenth, fourteenth, or fifteenth centuries. ${ }^{62}$ But the chronological connection is clear, and continues to be throughout the lifespan of sumptuary law: as fashion spread down the social scale, sumptuary laws dwindled, disappearing altogether in the eighteenth century at a point when fashion had become both universal and feminized, that is, less serious. ${ }^{63}$

\section{Conclusion}

Comparative study of the varieties of medieval sumptuary law can suggest many new approaches through which to understand an array of topics relevant to the mission of The Medieval Globe, and part of my purpose in writing this article was to join fellow historians in urging scholars in many fields to consider approaching sumptuary law and its underpinnings comparatively. ${ }^{64}$ Examined as a complex phenomenon, and treated with what Carol Symes calls "the dignity of being considered relevant and fully real," it becomes very clear that these laws had no instrumental function and were not really intended to. ${ }^{65}$ Sumptuary law has long been considered a "paradox," but we perceive it that way in part because we do not yet understand it. ${ }^{66}$ Analyzing sumptuary law as symbolic and aspirational, laden with hidden meanings and contests, is one step towards clarifying our understanding; considering sumptuary law as a global phenomenon with multiple variants, and thus approaching it comparatively, is another.

62 In my view, the system was not manifest until the fourteenth century, when the crucial component of continual rapid change was added. See Wilson, "De Novo Modo."'

63 See Belfanti and Giusberti, "Clothing and Social Inequality," who describe fashion as "taking the place" of sumptuary law in establishing social categories (362).

64 See note 3 above.

65 Symes, "When We Talk about Modernity," 717.

66 Hunt, Governance of the Consuming Passions, 355. 


\section{Bibliography}

\section{Manuscript Sources}

Oxford, Bodleian Library, MS Bodl. 264

Paris, Bibliothèque nationale de France, MS fr. 122

\section{Primary Sources}

Cortes de los antiguos reinos de León y de Castilla. Vol. 1. Madrid: Real Academia de la Historia, 1861.

Edward III, 1351-1377. Edited by W. Mark Ormrod. Vol. 5 of The Parliament Rolls of Medieval England, 1275-1514. Woodbridge: Boydell, 2005.

Sacchetti, Franco. Novelle di Franco Sacchetti. Edited by Giovanni Silvestri. Vol. 3. Milan, 1815.

Las siete partidas del Don rey Alfonso el Sabio, contejadas con varios codices antiguos por la Real academia de la historia. Vol. 2. Madrid: Real Academia de la Historia, 1807.

\section{Secondary Studies}

Anderssen, Eva I. "Foreign Seductions: Sumptuary Laws, Consumption, and National Identity in Early Modern Sweden." In Fashionable Encounters: Perspectives and Trends in Textile and Dress in the Early Modern Nordic World, edited by Tove Engelhardt Mathiassen, Marie-Louise Nosch, and Maj Ringgard, 15-30. Oxford: Oxford Books, 2014.

Asenjo-Gonzalez, Maria, ed. Urban Elites and Aristocratic Behaviour in the Spanish Kingdoms at the End of the Middle Ages. Turnhout: Brepols, 2013.

Baldwin, Frances E. Sumptuary Legislation and Personal Regulation in England. Baltimore: Johns Hopkins University Press, 1926.

Baudrillart, Henri. Histoire du luxe privé et public depuis l'antiquité jusqu'à nos jours. Vol. 3, Le Moyen âge et la Renaissance. 2nd ed. Paris: Hachette et Cie, 1881.

Beebe, Barton. "Intellectual Property Law and the Sumptuary Code." Harvard Law Review 123 (2010): 810-89.

Belfanti, Carlo Marco, and Fabio Giusberti. "Clothing and Social Inequality in Early Modern Europe: Introductory Remarks." Continuity and Change 15 (2000): 359-65.

Blanc, Odile. "From Battlefield to Court: The Invention of Fashion in the Fourteenth Century." In Encountering Medieval Textiles and Dress: Objects, Texts, Images, edited by Désirée Koslin and Janet E. Snyder, 157-72. New York: Palgrave Macmillan, 2002. 
Breward, Christopher. The Culture of Fashion: A New History of Fashionable Dress. Manchester: Manchester University Press, 1995.

Brown, A. L. The Governance of Late Medieval England, 1272-1461. Stanford: Stanford University Press, 1989.

Bulst, Neithard. "La legislazione suntuaria in francia (secoli XIII-XVIII)." In Disciplinare il lusso: la legislazione suntuaria in Italia e in Europa tra medieoevo ed età moderna, edited by Maria Giuseppina Muzzarelli and Antonella Campanini, 121-36. Rome: Carocci, 2003.

—_. "Les ordonnances somptuaires en Allemagne: expression de l'ordre urbain (XIV ${ }^{\mathrm{e}} \mathrm{XVI}^{\mathrm{e}}$ siècle)." In Comptes rendus des séances de l'année, 771-84. Paris: Académie des Inscriptions et Belles-Lettres, 1993.

—_ "Zum Problem städtischer und territorialer Kleider-, Aufwands- und Luxusgesetzgebung in Deutschland (13. - Mitte 16. Jahrhundert)." In Renaissance du pouvoir législatif et genèse de l'État, edited by André Gouron and Albert Rigaudière, 29-57. Montpellier: [Société d'histoire du droit et des institutions des anciens pays de droit écrit], 1988.

Burkholder, Kristen M. “Threads Bared: Dress and Textiles in Late Medieval English Wills." Medieval Clothing and Textiles 1 (2005): 133-53.

Buylaert, Frederik, Wim DeClerq, and Jan Dumolyn. "Sumptuary Legislation, Material Culture and the Semiotics of 'Vivre Noblement' in the County of Flanders (14th-16th Centuries)." Social History 36 (2011): 393-417.

Coss, Peter R. "Knights, Esquires, and the Origin of Social Gradation in England." Transactions of the Royal Historical Society, 6th ser., 5 (1995): 155-77.

—. The Origins of the English Gentry. Cambridge: Cambridge University Press, 2003.

Crane, Susan. The Performance of Self: Ritual, Clothing, and Identity During the Hundred Years War. Philadelphia: University of Pennsylvania Press, 2002.

Denny-Brown, Andrea. Fashioning Change: The Trope of Clothing in High-and LateMedieval England. Columbus: Ohio State University Press, 2012.

_. "Rips and Slits: "The Torn Garment and the Medieval Self." In Clothing Culture, 1350-1650, edited by Catherine Richardson, 223-37. Aldershot: Ashgate, 2004.

Doda, Hilary. “'Saide Monstrous Hose': Compliance, Transgression and English Sumptuary Law to 1533.” Textile History 45 (2014): 171-91.

Dodd, Gwilym. Justice and Grace: Private Petitioning and the English Parliament in the Late Middle Ages. Oxford: Oxford University Press, 2007.

Dumolyn, Jan. "Later Medieval and Early Modern Urban Elites: Social Categories and Social Dynamics." In Urban Elites and Aristocratic Behaviour in the Spanish Kingdoms at the End of the Middle Ages, edited by Maria Asenjo-Gonzalez, 3-18. Turnhout: Brepols, 2013. 
Frick, Carole Collier. Dressing Renaissance Florence: Families, Fortunes \& Fine Clothing. Baltimore: Johns Hopkins University Press, 2002.

Friedman, John Block. "The Iconography of Dagged Clothing and Its Reception by Moralist Writers." Medieval Clothing and Textiles 9 (2013): 121-38.

Goddard, Jennifer. "Anticipated Impact of the 2009 Four Corners Raid and Arrests." Crime, Law, and Social Change 56 (2011): 175-88.

González Arce, José Damián. Apariencia y poder: la legislación suntuaria castellana en los siglos XIII y XV. Jaén: Universidad de Jaén, 1998.

Greenfield, Kent Roberts. Sumptuary Law in Nürnberg: A Study in Paternal Government. Baltimore: Johns Hopkins University Press, 1918.

Gusfield, Joseph R. "Moral Passage: The Symbolic Process in Public Designations of Deviance." Social Problems 15, no. 2 (1967): 175-88.

_ . "On Legislating Morals: The Symbolic Process of Designating Deviance." California Law Review 56 (January 1968): 54-73.

Hayward, Maria. Rich Apparel: Clothing and the Law in Henry VIII's England. Aldershot: Ashgate, 2009.

Heller, Sarah-Grace. "Anxiety, Hierarchy, and Appearance in Thirteenth-Century Sumptuary Laws and the Roman de la rose." French Historical Studies 27 (Spring 2004): 311-48.

— Fashion in Medieval France. Cambridge: Brewer, 2007.

—_. "Limiting Yardage and Changes of Clothing in Thirteenth-Century France, Languedoc, and Italy." In Medieval Fabrications: Dress, Textiles, Cloth Work, and Other Cultural Imaginings, edited by E. Jane Burns, 122-36. New York: Palgrave Macmillan, 2004.

Hollander, Anne. Sex and Suits. New York: Knopf, 1994.

Hughes, Diane Owen. "Distinguishing Signs: Ear-Rings, Jews and Franciscan Rhetoric in the Italian Renaissance City." Past \& Present 112 (1986): 3-59.

_ . "Regulating Women's Fashion." In Silences of the Middle Ages, edited by Christine Klapisch-Zuber, 136-58. (Vol. 2 of A History of Women in the West, edited by Georges Duby and Michelle Perrot.) Cambridge: Cambridge University Press, 1992.

_. "Sumptuary Law and Social Relations in Renaissance Italy." In Disputes and Settlements: Law and Human Relations in the West, edited by John Bossy, 69-100. Cambridge: Cambridge University Press, 1983.

Hunt, Alan. Governance of the Consuming Passions: A History of Sumptuary Law. New York: St. Martin's Press, 1996.

Jaritz, Gerhard. "Kleidung und Prestige-Konkurrenz: unterschiedliche Identitäten in der städtischen Gesellschaft unter Normierungszwängen." Saeculum: Jahrbuch für Universalgeschichte 44 (1993): 8-31. 
Killerby, Catherine Kovesi. "Heralds of a Well-Instructed Mind: Nicola Sanuti's Defence of Women and Their Clothes." Renaissance Studies 13 (1999): 255-82.

_. "Practical Problems in the Enforcement of Italian Sumptuary Law, 12001500." In Crime, Society and the Law in Renaissance Italy, edited by Trevor Dean and Kate Lowe, 99-120. Cambridge: Cambridge University Press, 1994.

—. Sumptuary Law in Italy, 1200-1500. Oxford Historical Monographs. Oxford: Clarendon Press, 2002.

Lachaud, Frédérique, " La 'formation de la gentry,' XI ${ }^{\mathrm{e}}-\mathrm{XIV}{ }^{\mathrm{e}}$ siècle: un nouveau concept historiographique?" In Histoires d'outre-Manche: tendances récentes de l'historiographie britannique, edited by Frédérique Lachaud, Isabelle LescentGiles, and Francois-Joseph Ruggiu, 13-36. Paris: Presses de l'Université de Paris-Sorbonne, 2001.

Langlois, Charles V. "Project for Taxation Presented to Edward I." English Historical Review 4 (1889): 517-21.

Lansing, Carol. Passion and Order: Restraint of Grief in the Medieval Italian Communes. Ithaca: Cornell University Press, 2008.

Laver, James. A Concise History of Costume. London: Thames and Hudson, 1969.

Lemire, Beverly, and Giorgio Riello. "East and West: Textiles and Fashion in Early Modern Europe." Journal of Social History 41 (2008): 887-916.

Lipovetsky, Gilles. L'Empire de l'éphémère: la mode et son destin dans les sociétés modernes. Paris: Gallimard, 1987.

Miller, Robert D. Chieftains of the Highland Clans: A History of Israel in the Twelfth and Eleventh Centuries B.C. Eugene: Wipf \& Stock, 2012.

Moeti, Kabelo, and T. Khalo. Public Finance Fundamentals. Cape Town, South Africa: Juta, 2007.

Muzzarelli, Maria Giuseppina. "Una società nello specchio della legislazione suntuaria: il caso dell'Emilia-Romagna." In Disciplinare il lusso: la legislazione suntuaria in Italia e in Europa tra medieoevo ed età moderna, edited by Maria Giuseppina Muzzarelli and Antonella Campanini, 17-32. Rome: Carocci, 2003.

_ . "Reconciling the Privilege of a Few with the Common Good." Journal of Medieval and Early Modern Studies 39 (2009): 597-617.

Muzzarelli, Maria Giuseppina, and Antonella Campanini, eds. Disciplinare il lusso: La legislazione suntuaria in Italia e in Europa tra medieoevo ed età moderna. Rome: Carocci, 2003.

Newton, Stella Mary. Fashion in the Age of the Black Prince: A Study of the Years 1340-1365. Woodbridge: Boydell, 1980; repr. 1999.

Ormrod, W. Mark. "Introduction, Edward III: October 1363." In Parliament Rolls of Medieval England, edited by Chris Given-Wilson et. al. <http://www.britishhistory.ac.uk/no-series/parliament-rolls-medieval/october-1363> [accessed 15 September 2015]. 
Page, Agnès. Vêtir le prince: tissus et couleurs à la Cour de Savoie, 1427-1447. Lausanne: Section d'histoire, Faculté des lettres, Université de Lausanne, 1993.

Phillips, Kim M. "Masculinities and the Medieval English Sumptuary Laws" Gender \& History 19 (2007): 22-42.

Piponnier, Françoise. Costume et vie sociale; la cour d'Anjou XIVe-XVe siècle. Paris: Mouton, 1970.

Rainey, Ronald. "Sumptuary Legislation in Renaissance Florence." PhD diss., Columbia University, 1985.

Riello, Giorgio, and Prasannan Parthasarathi. The Spinning World: A Global History of Cotton Textiles, 1200-1850. Oxford: Oxford University Press, 2009.

Roche, Daniel. La culture des apparences: une histoire du vêtement (XVIIe-XVIIIe siècle). Paris: Fayard, 1989.

Schick, Irvin Cemil. "Some Islamic Determinants of Dress and Personal Appearance in Southwest Asia." Khil'a 3 (2007-9): 25-53.

Sempere y Guarinos, Juan. Historia del Luxo y de las Leyes Suntuarias de Espaǹa. Vol. 1. Madrid, 1788.

Shively, Donald. "Sumptuary Regulation and Status in Early Tokugawa Japan." Harvard Journal of Asiatic Studies 25 (1964-65): 123-64.

Sponsler, Claire. "Narrating the Social Order: Medieval Clothing Laws," Clio 21 (1992): 265-83.

Stuard, Susan Mosher. Gilding the Market: Luxury and Fashion in Fourteenth-Century Italy. Philadelphia: University of Pennsylvania Press, 2006.

Symes, Carol. "When We Talk about Modernity." American Historical Review 116 (2011): 715-26.

Vincent, John Martin. Costume and Conduct in the Laws of Basel, Bern, and Zurich, 1370-1800. Baltimore: Johns Hopkins University Press, 1935.

Vincent, Susan. Dressing the Elite: Clothes in Early Modern England. Oxford: Berg, 2003.

Ware, Anthony. "Origins of Buddhist Nationalism in Myanmar/Burma? An Urban History of Religious Space, Social Integration and Marginalisation in Colonial Rangoon after 1852." In Religion and Urbanism: Reconceptualising Sustainable Cities for South Asia, edited by Yamini Narayanan. London: Routledge, 2015.

Wilson, Elizabeth. Adorned in Dreams: Fashion and Modernity. London: Virago, 1985.

Wilson, Laurel Ann. “'De Novo Modo': The Birth of Fashion in the Middle Ages.” PhD. diss., Fordham University, 2011.

—. "Status." In Fashion in the Medieval Age (500-1450), edited by Sarah-Grace Heller. [Vol. 2 of A Cultural History of Dress and Fashion, edited by Susan Vincent.] London: Bloomsbury, forthcoming. 
Wood-Legh, K. L. “The Knights' Attendance in the Parliaments of Edward III." English Historical Review 47 (1932): 398-413.

Zanda, Emanuala. Fighting Hydra-Like Luxury: Sumptuary Law in the Roman Republic. London: Bloomsbury 2011.

Laurel Ann Wilson (lwilson@fordham.edu) earned her PhD from Fordham University and is currently a Visiting Fellow at the Center for Medieval Studies at Fordham. Her interests include medieval textile technology and the emergence of fashion as a social phenomenon: the subject of her doctoral dissertation, as well as of many conference papers given under the auspices of the Pasold Research Fund, the North American Conference on British Studies, the Medieval Academy of America, and the International Congress on Medieval Studies. Her current research involves changes in the meaning of clothing in the later Middle Ages as reflected in sumptuary law, liveries, and dress codes. Forthcoming publications include "Status," in Fashion in the Medieval Age (500-1450), edited by Sarah-Grace Heller.

Abstract Medieval sumptuary law has been receiving renewed scholarly attention in recent decades. But sumptuary laws, despite their ubiquity, have rarely been considered comprehensively and comparatively. This essay calls attention to this problem and suggests a number of topics for investigation, with specific reference to the first phase of European sumptuary legislation in the thirteenth and fourteenth centuries. It argues that comparative study demonstrates that this chronology closely parallels the development of the so-called "Western fashion system" and that the ubiquity of sketchy or nonexistent enforcement is evidence for the symbolic importance of sumptuary legislation, rather than its instrumentality. Comparison across (modern) national boundaries further reveals intriguing patterns of similarity and difference that require further exploration and contextualization; for example, such research reveals that only one social category, that of knights, emerges as universally important during this period.

Keywords Sumptuary law, clothing, luxury, gentry, symbolic legislation, social classification, status, knight, Western fashion system 